\title{
CEREBRAL SALVAGE IN NEAR-DROWNING FOLLOWING NEUROLOGICAL CLASSIFICATION BY TRIAGE
}

\author{
A.W. Conn, J.E. Montes, G.A. Barker and J.F. Edmonds
}

ABSTRACT

This paper describes a simple neurological classification for near-drowning victims into three main categories consisting of:

\author{
Category A (Awake) \\ Category B (Blunted Consciousness) \\ Category C (Comatose). \\ Category $C$ is sub-classified into: \\ C.I (Decorticate) \\ C.2(Decerebrate) \\ C.3 (Flaccid).
}

This triage classification is based on the level of consciousness at a post-rescue time interval of approximately one to two hours, and functions as a guide to therapeutic management. Cerebral salvage results using this classification and comparing routine and aggressive therapy are reported in a retrospective review of 96 patients seen at The Hospital for Sick Children, Toronto, during a 10-year period (1970-1979 inclusive). Aggressive therapy for neurological purposes included cont inuous dehydration, controlled hyperventilation, moderate hypothermia, barbiturate coma, and continuous muscular paraly sis for four days.

All patients in categories A ( 51 cases) and B (6 cases) recovered completely using routine medical management.

In category C ( 39 comatose patients) there was an overall mortality of 33.3 per cent with a cerebral morbidity of 23.9 per cent and normal recovery in 43.6 per cent. When reviewing the results of treatment, two subcategories, (C.I and C.2) were combined for comparative purposes. Results in 14 cases using routine therapy revealed a mortality of 21.4 per cent. a morbidity of 42,8 per cent and an intact survival rate of 35.7 per cent. In comparison, 11 patients who received aggressive (H.Y.P.E.R.) therapy had no mortality, a morbidity of 9.0 per cent and a significant 90.9 per cent incidence of intact survival. In subcategory C. 3 (14 patients) there were only four survivors, with one patient in each treatment group surviving intact ( 14.2 per cent).

Intact cerebral survival is of paramount importance. Our findings justify immediate resuscitation in all near-drowning cases regardless of the patient's initial condition or possible prognosis. The use of an early neurological triage classification seems most appropriate to facilitate therapeutic management. Aggressive treatment (H.Y.P. E.R. therapy) in decorticate cases (subcategory C.1) and decerebrate cases (subcategory C.2) has led to a significant reduction in morbidity and mortality in near-drowned patients.

TRIAGE IS DEFINED as "the sorting out and classification of casualties of war or other disaster to determine priority of need and proper place of treatment". ' Near-Drowning ${ }^{2}$ victims also require individual assessment and categorization of their condition to facilitate proper therapeutic management. In conjunction with Dr. Jerome $H$. Modell, ${ }^{3}$ we have utilized a simple triage classification for an initial neurological assessment of these patients, in order to evaluate their subsequent course and make recommendations. This paper reports our cerebral 'salvage' results,

A.W.Conn, M.D., F.R.C.P.(C); J.E. Montes, M.D.; G.A. Barker, M.D., F.F.A.R.A.C.S.; J.F. Edmonds, M.B., F.R.C.P.(C), The Intensive Care Unit, Hospital For Sick Children, 555 University Avenue, Toronto, Canada M5G IX8.

Canad. Anaesth. Soc. J., vol. 27, no. 3, May 1980 classified by triage, in a retrospective review of 96 near-drowned children. The series includes all near-drowning patients who visited the emergency department, all admissions to the ward or intensive care unit, and all late admissions with neurological sequelae who were seen at the Hospital for Sick Children, Toronto, during 10-year period 1970 to 1979 inclusive.

\section{a Neurological Classification of Near-Drowning by Triage (Following RESUSCITATION)}

Following rescue, successful cardiopulmonary resuscitation and hospital admission, the clinician often faces an acute dilemma regarding future management. The selection of approptiate 
TABLE I

Morbidity and Mortality in Near-Drowning Cases

\begin{tabular}{lcccc}
\hline \hline & & \multicolumn{3}{c}{ Cases } \\
\cline { 3 - 5 } Category & Totals & Died & Brain damaged & Normal \\
\hline A (Awake) & 51 cases $(53.1 \%)$ & 0 & 0 & 51 \\
B (Blunted) & 6 cases $(6.2 \%)$ & 0 & 0 & 6 \\
C (Comatose) & 39 cases $(40.7 \%)$ & 13 & 9 & 17 \\
Totals & 96 cases $(100 \%)$ & $13(13.5 \%)$ & $9(9.3 \%)$ & $74(77.0 \%)$ \\
\hline
\end{tabular}

treatment may be very difficult if, for example, the duration of submersion is uncertain (unknown, erroneous or contradictory) and the asphyxial effects of a submersion time of twenty seconds versus twenty minutes are contrasted!

A suitable classification is required for therapeutic purposes which will be relevant to all cases of near-drowning, despite the many variable factors usually present. These factors, previously described, 4,12 include numerous physiological features (especially the activity of the 'diving' reflex), ${ }^{35-37}$ immersion hypothermia, ${ }^{30,38.39}$ submersion time, ${ }^{31-33}$ and the efficacy of initial ${ }^{40.41}$ and subsequent resuscitation. ${ }^{4.12}$ Unfortunatcly, these variables are uncontrolled and uncontrollable, but play a major role in the patient's subsequent course. This helps to explain the lack of agreement in near-drowning regarding the course and classification of cases ${ }^{16.44 .45 .47 .50 .51}$ and the selection of prognostic factors. ${ }^{16,46,48,49.59}$

Since complete cerebral recovery is of paramount importance, the most appropriate therapeutic guide is based on a clinical classification of the patient's level of consciousness. Since brain injury following submersion differs in many respects from that occurring in other situations such as cerebral trauma or Reye's Syndrome, the use of the Glasgow Coma Scale ${ }^{5}$ or Lovejoy's Coma Stages, ${ }^{6}$ for example, are not directly applicable. A basic triage classification is recommended jointly with Dr. J. Modell, ${ }^{3}$ which consists of three main categorics A (Awake), B (Blunted) and C (Comatose). This process establishes the therapeutic priorities which affect subsequent cerebral salvage. The patient's category is determined by the state of consciousness at a specific time interval, approximating one to two hours after rescue. ${ }^{25}$

Using this classification, our results are reportcd in Table I. It is apparent that all cerebral morbidity and all mortality occurred in category
TABLE II

A 'Triage' Classification of Near-Drowning Patients (Assessed at 1-2 hr after rescue)

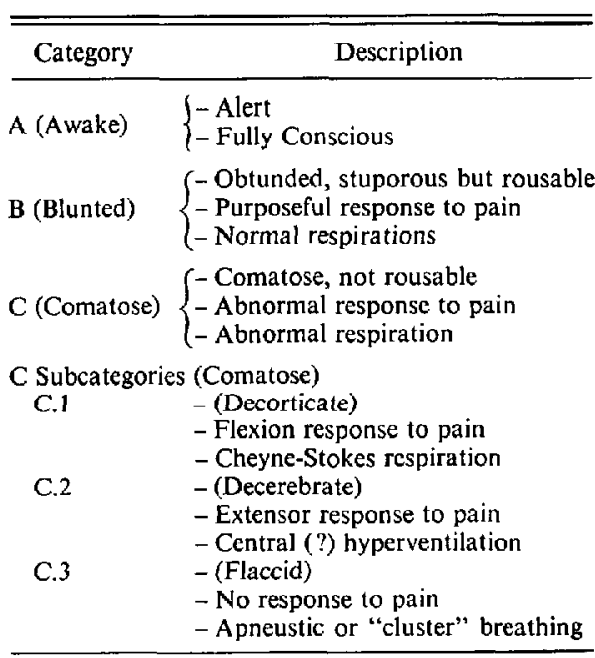

Cexclusively. Therefore, the category $C$ group of comatose patients was subdivided into three subcategories, C. 1 (Decorticate), C.2 (Decerebrate), and C.3 (Flaccid), according to the progressive depth of coma (Table II).

The sex and age distribution in the series are reported in Table III and Table IV. The high incidence in male children and in the younger (1-5 yr) age groups agree with previous reports. ${ }^{7,8}, 13,44,45$ A correspondingly high incidence in category $C$ is also evident. The annual distribution of cases is presented in Table $\mathrm{V}$ and reveals a sudden increase in cases since 1975. The increase occurs mainly in category $C$, suggesting more successful resuscitation.

The management and results in each category is reviewed and discussed in detail in the following sections. 
TABLE III

Sex Distribution of Near-Drowning Patients

\begin{tabular}{lrrrrrrrrr}
\hline & \multicolumn{3}{c}{ Category } & & & \multicolumn{3}{c}{ C Subgroups } \\
\cline { 2 - 4 } \cline { 6 - 8 } Sex & A & B & C & & Total $(\%)$ & C.1 & C.2 & C.3 & Total \\
\hline Male & 36 & 3 & 30 & & $69(71.9 \%)$ & 7 & 13 & 10 & 30 \\
Female & 15 & 3 & 9 & $27(28.1 \%)$ & 2 & 3 & 4 & 9 \\
Totals & 51 & 6 & 39 & 96 & 9 & 10 & 14 & 39 \\
\hline
\end{tabular}

TABLE IV

Age Distribution of Neak-Drowning Patients

\begin{tabular}{|c|c|c|c|c|c|c|c|c|}
\hline \multirow[b]{2}{*}{ Age } & \multicolumn{3}{|c|}{ Category } & \multirow[b]{2}{*}{ Total $(\%)$} & \multicolumn{3}{|c|}{ C Subgroups } & \multirow[b]{2}{*}{ Tota! } \\
\hline & $\mathrm{A}$ & B & $\mathrm{C}$ & & C. 1 & C. 2 & C. 3 & \\
\hline$<1 \mathrm{yr}$ & 5 & - & 1 & $6(6.2 \%)$ & - & 1 & - & 1 \\
\hline $1-5$ yrs. & 27 & 1 & 28 & $56(58.3 \%)$ & 9 & 12 & 7 & 28 \\
\hline $6-10$ yrs. & 9 & 3 & 8 & $20(20.8 \%)$ & 3 & 2 & 3 & 8 \\
\hline$>10$ yrs. & 10 & 2 & 2 & $14(14.6 \%)$ & - & - & 2 & 2 \\
\hline Totals & 51 & 6 & 39 & 96 & 12 & 15 & 12 & 39 \\
\hline
\end{tabular}

Discussion of Near-Drowning Cases by CATEGORY

\section{Category $A:($ Awake)}

These patients are awake and alert with minimal asphyxial injury, but require admission to hospital. Continuous observation is needed in the event that neurological, pulmonary, or other deterioration occurs. After the usual history and physical examination, all routine laboratory tests must be done, including arterial blood gases, serum electrolytes, blood and throat cultures, and chest $x$-ray films. The use of antibiotics remains controversial, 9 but symptomatic therapy is all that is usually required. After 12 to 24 hours, a thorough re-examination and complete reassessment should be done before discharge home. A follow-up programme in one to two days will reveal later complications such as pulmonary infection.

There were 51 cases in category A $(53.1$ per cent of the total). All were discharged from the hospital as completely normal and none required re-admission. These results are contrasted with Fuller's mortality in 77 drowned patients of whom 18.2 per cent were awake on admission but subsequently died. ${ }^{10}$ No causes of death were given, but late death from pulmonary infection has been reported in this group. "'
TABLE $V$

Annual Distribution of Near-Drowning Patients

\begin{tabular}{|c|c|c|c|c|c|c|c|c|}
\hline \multirow[b]{2}{*}{ Year } & \multicolumn{3}{|c|}{ Category } & \multirow[b]{2}{*}{ Total } & \multicolumn{3}{|c|}{ "C" Subgroups } & \multirow[b]{2}{*}{ Total } \\
\hline & A & $\mathrm{B}$ & $\mathrm{C}$ & & C. 1 & C. 2 & C. 3 & \\
\hline 1970 & 2 & 0 & 3 & 5 & 2 & 1 & 0 & 3 \\
\hline 1971 & 6 & 0 & 0 & 6 & 0 & 0 & 0 & 0 \\
\hline 1972 & 3 & 1 & 2 & 6 & 0 & 1 & 1 & 2 \\
\hline 1973 & 5 & 0 & 4 & 9 & 0 & 2 & 2 & 4 \\
\hline 1974 & 4 & 0 & 3 & 7 & 2 & 0 & 1 & 3 \\
\hline $5 \mathrm{yrs}$. & 20 & 1 & 12 & 33 & 4 & 4 & 4 & 12 \\
\hline 1975 & 9 & 0 & 3 & 12 & 2 & 1 & 0 & 3 \\
\hline 1976 & 5 & 0 & 1 & 6 & 0 & 1 & 0 & 1 \\
\hline 1977 & 5 & 2 & 7 & 14 & 2 & 2 & 3 & 7 \\
\hline 1978 & 4 & 1 & 6 & 11 & 0 & 5 & 1 & 6 \\
\hline 1979 & 8 & 2 & 10 & 20 & 1 & 3 & 6 & 10 \\
\hline 5 yrs. & 31 & 5 & 27 & 63 & 5 & 12 & 10 & 27 \\
\hline $10 \mathrm{yrs}$ & 51 & 6 & 39 & 96 & 9 & 16 & 14 & 39 \\
\hline
\end{tabular}

\section{Category B: (Blunted)}

This group of patients is semi-conscious from more serious asphyxia, but they have normal pupillary reactions and purposeful responses to pain. Close continuous observation is essential, and careful monitoring of respiratory and cir- 
culatory parameters is necessary for the first 24 hours. Because the level of consciousness may change rapidly and clinical signs lag behind a rise in intracranial pressure, the normal routine followed for a head injury should be used to detect any deterioration in neurological state.

Until full consciousness returns, certain specific therapeutic measures are recommended in addition to the treatment outlined under Category $\mathrm{A}$. These special measures are intended to prevent or to reduce intracranial hypertension and include initial diuresis, restriction of fluid to half of maintenance requirements, increased concentrations of inspired oxygen and maintenance of normothermia. Subsequent therapy is related to the patient's progress.

These patients will require a longer stay in the intensive care unit because of the high incidence of pulmonary aspiration, ${ }^{10.14}$ but most will recover uneventfully. A potentially unfavourable course may be foreseen by indirect evidence of severe anoxia, such as intractable metabolic acidosis, a prolonged resuscitation, or gross pulmonary oedema. Clinical guidelines are unreliable in this group, so if these findings are accompanied by progressive neurological depression, the patient should be reclassified into category $C$.

There were six patients in category $B(6.2$ per cent) during the period 1970-1979. Since these patients suffer more severe asphyxia and are more liable to pulmonary as well as to cercbral complications, all should be admitted to hospital for 24-48 hours. All children in this group also had recovered completely at the time of discharge.

It is noted that all patients in categories A and B (57 cases) recovered completely with routine medical management. This group includes two patients in category $C .1$ at rescue who improved rapidly to category $A$ during the subsequent two hours. There were also two patients in category $A$ at rescue who deteriorated neurologically and are included in category C.1. Many others changed just one category or subcategory in the early post-rescue period.

\section{Category C:(Comatose)}

The group of 39 patients in category $C$ suffered severe asphyxia and were all in a state of coma with abnormal responses to pain and abnormal patterns of respirations. The depth of coma, according to their clinical responses ${ }^{53.54}$ was grouped into three subcategories, C.I (decorticate), C.2 (decerebrate) and C. 3 (flaccid), each with a correspondingly poorer prognosis. It is obvious that only in this comatose group can the results of treatment be compared.

The rationale for aggressive therapy to improve cerebral salvage is as follows. Any acute brain injury, including asphyxia from neardrowning, will cause abolition of neuronal function, oedema, vasomotor paralysis (hyperaemia), and tissue acidosis. ${ }^{56}$ It is now believed that neurones which survive the primary brain insult and could recover, often die secondarily from the effects of cerebral oedema ${ }^{25}$ or raised intracranial pressure as a result of brain swelling. ${ }^{26,28}$ Therapeutic measures are primarily directed at the control of intracranial pressure, but a direct neuronal effect by hypothermia ${ }^{26}$ and barbiturate $\operatorname{coma}^{21,22}$ is possible. The onset of intracranial hypertension is variable in time, but the more severe the injury the earlier the onset. The lethal effects on the brain of a continuously high intracranial pressure are too well known for further comment. In instances of severe asphyxia, this process is predictable, often preventable, and usually controllable. Since a damaged brain is extremcly susceptible to hypoxia, and pulmonary oedema with hypoxaemia is usually present, ${ }^{15,16}$ this complication must be rigorously controlled by using diuretics, high positive end-expiratory pressure (PEEP), and high concentrations of inspired oxygen. Other complications ${ }^{52}$ affecting cerebral recovery to a lesser extent are omitted from this paper.

\section{Management of Category C Patients}

At the time of admission, a victim of neardrowning may appear to be dead cerebrally or show substantial evidence of brain injury. The high incidence of death or permanent brain damage in category $C$ is confirmed in this series. Only six patients ( 28.5 per cent) out of 21 comatose cases in this category recovered completely with routine treatment, whereas aggressive therapy (outlined later) in patients in the same category produced an intact survival of 11 patients (61.1 per cent) in 18 cases. The incidence of brain damage also diminished from eight patients ( 38.1 per cent) in 21 cases to one patient ( 5.5 per cent) in 18 cases.

Our overall percentage figures in 39 comatose cases (Category C), can be compared with 18 comatose cases in Dr. Modell's paediatric series ${ }^{3}$ as follows: mortality 33.3 per cent vs 39 per cent; morbidity 23.9 per cent vs 17 per cent; normal 43.6 per cent vs 44 per cent. The similarity might be explained by our 14 patients known to be in the 
C.3 (Flaccid) subcategory (or deepest coma) which weighted the series. Nevertheless a comparison of the treated and untreated cases in subcategories C. 1 and C. 2 as presented in Table VII reveals a significant difference in our neurological results with aggressive treatment.

Therefore an assumption should be made that the brain injury is reversible and early and aggressive therapeutic measures should be initiated. The introduction of single or sequential methods of treatment is not our practice, since all measures to achieve these goals should be implemented and must take priority over the treatment of other body systems. The twin goals of cerebral salvage are to preserve those neurones that are viable, but non-functioning, and to prevent a significant rise in intracranial pressure.

Our therapeutic regimen for all category $C$ cases was derived from personal experience. conversations with Dr. M. Spence ${ }^{57}$ of Auckland, N.Z. and his treatment as reported by Dr. R. Trubuhovich ${ }^{17}$ and previous reports. ${ }^{43}$ Our regimen has been given the acronym 'H.Y.P.E.R.' ${ }^{4.12}$ based on the usual clinical state of the comatose near-drowned patient on admission (i.e. these patients are hyper-hydrated and hyper-ventilating with hyper-pyrexia, hyperexcitability and hyper-rigidity). These five findings suggest the corresponding therapeutic measures for critical cerebral care. This treatment has evolved continuously since first reported in $1976^{18}$ and may be considered therapeutic "overkill", but seems justified by the results. The measures, as currently applied, are summarized as follows.

\section{Hyper-hydration}

This problem ${ }^{4,27}$ is best controlled by commencing treatment as soon as the circulation is completely stable. Initial treatment consists of the immediate administration of furosemide 0.5 to $1.0 \mathrm{mg} \cdot \mathrm{kg}^{-1}$ intravenously, repeated until adequate diuresis occurs. Later, fluid restriction to one third of the maintenance requirements is instituted and continued until cerebral compliance returns to normal, consciousness is regained, or clinical or laboratory evidence of dehydration is detected. It is essential that fluid balance be accurately controlled, and that continuous direct measurement of electrocardiogram, central venous pressure, blood pressure, and possibly pulmonary capillary wedge pressure be made. When available, daily cardiac index and blood volume measurements may confirm other clinical findings.

\section{Hyper-ventilation}

After global asphyxia, cerebral shunts or steals from alterations in autoregulation cannot be determined. Therefore, the $\mathrm{Pa}_{\mathrm{CO}_{2}}$ is arbitrarily maintained at $4 \mathrm{kPa}(30 \mathrm{~mm} \mathrm{Hg})$. This level is controversial and represents a compromise between hypocapnia with possible excessive cerebral vasoconstriction, and normocapnia or hypercapnia with excessive cerebral blood flow and raised intracranial pressure. Nevertheless, if an abrupt rise of intracranial pressure occurs, hyperventilation can be increased temporarily to deal with such an emergency.

The high concentration of inspired oxygen is maintained as required, and the risk of pulmonary toxicity is accepted. A high arterial oxygen tension (>20 kPa [150 torr]) theoretically favours diffusion of oxygen through oedematous percapillary areas of the brain. A PEEP of 0.67 to $1.33 \mathrm{kPa}(5-10 \mathrm{~mm} \mathrm{Hg})^{58}$ provides adequate oxygenation in most cases, prevents pulmonary micro-atelectasis, and avoids a possible rise of cerebral venous pressure (intracranial pressure). Nevertheless, prolonged continuous paralysis can lead to major $\dot{V} / Q$ abnormalities ${ }^{60}$ and routine changes of position are recommended to prevent this.

\section{Hyper-pyrexia}

Using a cooling mattress and relaxants, body temperature should be rapidly reduced and maintained at $30 \pm 1^{\circ} \mathrm{C}$. This level achieves a satisfactory reduction in both cerebral oxygen requirements $5^{29}$ and intracranial pressure and is above the upper level for spontaneous ventricular fibrillation (approximately $28^{\circ} \mathrm{C}$ ). Obviously rectal or other core temperatures must be monitored continuously.

Hypothermia suppresses normal immune response so that daily bacterial cultures from blood, trachea and bladder are essential. In addition white cell counts and platelet counts may provide additional evidence of infection. The prophylactic use of antibiotics remains controversial.

\section{Hyper-excitability}

Barbiturates have been used recently in large doses to protect the brain. ${ }^{19-21}$ Their mode of action includes reduction of intracranial pressure from cerebral vasoconstriction and a probably direct beneficial effect on neurones, although the exact mechanism remains controversial. The summation of beneficial metabolic effects of barbiturate treatment when combined with 
TABLE VI

Results of Treatment in Category C Patients (1970-1979)

\begin{tabular}{|c|c|c|c|c|c|}
\hline \multirow[b]{2}{*}{ Category } & \multirow[b]{2}{*}{ Total } & \multirow[b]{2}{*}{ Treatment } & \multicolumn{3}{|c|}{ Results (Cases) $(\%)$} \\
\hline & & & Dead & Damaged & Normal \\
\hline \multirow{4}{*}{$\begin{array}{l}\text { C.1 Comatose } \\
\text { (Decorticate) }\end{array}$} & 9 cases & $(-) 4$ cases & 0 & 2 & 2 \\
\hline & & (Ғ) 4 cases & 1 & 0 & 3 \\
\hline & & $(+) 1$ case & 0 & 0 & 1 \\
\hline & Totals & 9 cases & $1(11.1 \%)$ & $2(22.2 \%)$ & $6(66.0 \%)$ \\
\hline \multirow{4}{*}{$\begin{array}{l}\text { C. } 2 \text { Comatose } \\
\text { (Decerebrate) }\end{array}$} & 16 cases & (-) 5 cases & 2 & 3 & 0 \\
\hline & & (Ғ) 1 case & 0 & 1 & 0 \\
\hline & & ( +10 cases & 0 & 1 & 9 \\
\hline & Totals & 16 cases & $2(12.5 \%)$ & $5(31.2 \%)$ & $9(56.2 \%)$ \\
\hline \multirow{4}{*}{$\begin{array}{l}\text { C. } 3 \text { Comatose } \\
\text { (Flaccid) }\end{array}$} & 14 cases & (-) 6 cases & 4 & 1 & 1 \\
\hline & & (Ғ) 1 case & 0 & 1 & 0 \\
\hline & & $(+) 7$ cases & 0 & 0 & 1 \\
\hline & Totals & 14 cases & $10(71.4 \%)$ & $2(14.2 \%)$ & $2(14.2 \%)$ \\
\hline Combined Totals & 39 cases & 39 cases & $13(33.3 \%)$ & $9(23.9 \%)$ & $17(43.6 \%)$ \\
\hline
\end{tabular}

$(-)$ indicates routine supportive treatments.

$(\mp)$ indicates that one or two of the H.Y.P.E.R. measures were used.

$(+)$ indicates H.Y.P.E.R. therapy.

hypothermia has been reported ${ }^{20}$ and refuted. ${ }^{22}$ Steroids are ineffective in the treatment of the pulmonary lesion in fresh-water drowning ${ }^{23}$ but are known to prevent a rise in intracranial pressure ${ }^{24,26}$ and to improve cerebral compliance. Currently, recommended doses are:

1. Phenobarbitone $50 \mathrm{mg} \cdot \mathrm{kg}^{-1}$ on the first day, given slowly intravenously in three divided doses, and $25 \mathrm{mg} \cdot \mathrm{kg}^{-1}$ in three divided doses on the second, third, and fourth days of treatment. Daily determinations of barbiturate blood level are necessary to achieve the optimal therapeutic goal of 75 to $100 \mathrm{mg}$ per litre. In some patients we have observed that the spinal fiuid barbiturate levels are approximately half the blood levels, and that barbiturate levels may rise for 24 hours after therapy is discontinued. A long-acting barbiturate (40 hours using phenobarbitone) is preferred to other barbiturates because circulatory depression is minimal and treatment can be promptly reinstituted if intracranial pressure rises unexpectedly.

2. Dexamethasone, loading dose $0.2 \mathrm{mg} \cdot \mathrm{kg}^{-1}$ : maintenance $0.1 \mathrm{mg} \cdot \mathrm{kg}^{-1}$ every six hours. Start treatment within six hours.

\section{Hyper-rigidity}

Decorticate or decerebrate rigidity is an obvious clinical cause of raised intracranial pressure. However, simple nursing procedures such as lowering the head or tracheal suctioning may precipitate a rise in intracranial pressure of $30 \mathrm{~min}-$ utes duration. For these reasons, as well as for the need to control ventilation, which lowers intracranial pressure, complete muscle paralysis is maintained continuously. For this purpose, we use intravenous d-tubocurare 0.5 to $1.0 \mathrm{mg} \cdot \mathrm{kg}^{-1}$, or intravenous pancuronium $0.1 \mathrm{mg} \cdot \mathrm{kg}^{-1}$ either hourly or as needed, to prevent all movement. Later, when all relaxant therapy is discontinued and weaning from the respirator is commenced, a nerve stimulator should be employed to test for residual curarization (up to three days).

It is obvious that any emergency department can initiate H.Y.P.E.R. therapy following cardiopulmonary resuscitation of a near-drowning victim. It is recommended that subsequently the patient be safely transported for continued treatment to a regional critical care unit where personnel and extensive monitoring facilities are continuously available.

The value of each individual treatment in this regimen is uncertain, and the optimal drug dosages have not yet been verified. Theoretically, each therapeutic measure should facilitate cerebral recovery but their qualitative and quantitative effects await prolonged and careful clinical study. Nevertheless, it has been possible in our institution to make a significant improvement in cerebral salvage ${ }^{4,12}$ (see Table VI and Table VII). 
TABLE VII

Results Comparing Treatment in Category C Patients

\begin{tabular}{|c|c|c|c|c|c|}
\hline \multirow[b]{2}{*}{ Category } & \multirow[b]{2}{*}{ Total } & \multirow[b]{2}{*}{ Treatment } & \multicolumn{3}{|c|}{ Results (Cases) $(\%)$} \\
\hline & & & Dead & Damaged & Normal \\
\hline \multirow[t]{2}{*}{$\begin{array}{l}\text { C. } 1 \text { Comatose } \\
\text { (Decorticate) }\end{array}$} & $\begin{array}{l}8 \text { cases } \\
1 \text { case }\end{array}$ & $\begin{array}{l}\text { Routine }(-)(\mp) \\
\text { H.Y.P.E.R. }(+)\end{array}$ & $\begin{array}{l}1(12.5 \%) \\
0\end{array}$ & $\begin{array}{l}2(25 \%) \\
0\end{array}$ & $\begin{array}{l}5(62.5 \%) \\
1(100 \%)\end{array}$ \\
\hline & 9 cases & & 1 & 2 & 6 \\
\hline \multirow[t]{2}{*}{$\begin{array}{l}\text { C.2 Comatose } \\
\text { (Decerebrate) }\end{array}$} & $\begin{array}{l}6 \text { cases } \\
10 \text { cases }\end{array}$ & $\begin{array}{l}\text { Routine }(-)(\mp) \\
\text { H.Y.P.E.R. }(+)\end{array}$ & $\begin{array}{l}2(33.3 \%) \\
0\end{array}$ & $\begin{array}{l}4(66.6 \%) \\
1(10 \%)\end{array}$ & $\begin{array}{l}0 \\
9(90 \%)\end{array}$ \\
\hline & 16 cases & & 2 & 5 & 9 \\
\hline \multirow[t]{2}{*}{$\begin{array}{l}\text { C. } 3 \text { Comatose } \\
\text { (Flaccid) }\end{array}$} & $\begin{array}{l}7 \text { cases } \\
7 \text { cases }\end{array}$ & $\begin{array}{l}\text { Routine }(-)(\mp) \\
\text { H.Y.P.E.R. }(+)\end{array}$ & $\begin{array}{l}4(57.1 \%) \\
6(85.7 \%)\end{array}$ & $\begin{array}{l}2(28.4 \%) \\
0\end{array}$ & $\begin{array}{l}1(14.2 \%) \\
1(14.2 \%)\end{array}$ \\
\hline & 14 cases & & 10 & 2 & 2 \\
\hline \multirow[t]{2}{*}{$\begin{array}{l}\text { Combined } \\
\text { C.1 and C. } 2\end{array}$} & $\begin{array}{l}14 \text { cases } \\
11 \text { cases }\end{array}$ & $\begin{array}{l}\text { Routine }(-)(\mp) \\
\text { H.Y.P.E.R. }(+)\end{array}$ & $\begin{array}{l}3(21.4 \%) \\
0\end{array}$ & $\begin{array}{l}6(42.8 \%) \\
1(9.0 \%)\end{array}$ & $\begin{array}{r}5(35.7 \%) \\
10(90.9 \%)\end{array}$ \\
\hline & 25 cases & & 3 & 7 & $15(P<0.02)^{*}$ \\
\hline
\end{tabular}

$(-)$ indicates routine supportive treatment.

(F) indicates that one or two of the H.Y.P.E.R. measures were used.

$(+)$ indicates H.Y.P.E.R. therapy.

*The results of routine and H.Y.P.E.R. therapy in the combined C.I and C.2 sub-groups were compared by Fisher's exact probability test.

When using H.Y.P.E.R. therapy, cerebral monitoring is limited to a few measures which become of paramount importance. The sole clinical evidence of cerebral change is obtained by observing changes in pupillary size or reactions. The monitoring of intracranial pressure is mandatory with direct continuous measurement by means of a Richmond screw or ventricular drain. A daily electroencephalogram (EEG) is valuable, as it will reveal abnormalities and barbiturate effect and, hopefully, will show progressive improvement.' After 12 to 24 hours the electroencephalogram is not flat at $30^{\circ} \mathrm{C}$ and levels of phenobarbitone of 75 to $100 \mathrm{mg}$ per litre, unless cerebral death has occurred. A cerebral function monitor may provide additional help and is presently under investigation.

Based on experience, it is recommended that a minimum of four days treatment is necessary to control cerebral swelling effectively and to prevent relapses. Any major rise in intracranial pressure spontaneously, or from mild stimulation, indicates that the brain is still damaged and swollen and will require an additional two days of therapy. If intermittent rises of intracranial pressure ( $\geq 2.66$ to $3.33 \mathrm{kPa}$ [20 to $25 \mathrm{~mm} \mathrm{Hg}$ ) occur, treatment consists of vigorous hyperventilation until 3 to $5 \mathrm{mg} \cdot \mathrm{kg}^{-1}$ of thiopentone can be administered intravenously. These measures can be supplemented by administration of mannitol when necessary. A computerized tomography scan is recommended to rule out a spaceoccupying lesion when intracranial pressure rises unexpectedly or repeatedly.

When the decision to discontinue therapy is made, phenobarbitone and relaxants are stopped and the patient is allowed to rewarm passively over a 24 -hour period and to regain consciousness, which usually takes one to four days. Reinstitution of treatment is easily undertaken if required, but has not been required in any of our near-drowned patients.

\section{Results in Category C Patients}

Immediate resuscitation is recommended in all cases of near-drowning despite a report to the contrary. ${ }^{16}$ A number of factors can delay the onset of brain death, especially in cold water drowning, ${ }^{30-34}$ and justify extensive resuscitation efforts regardless of the victim's initial condition. ${ }^{42}$ As a result of this policy, there has been an increase in the number of patients admitted in a comatose state including subcategory C. 3 (Flaccid). This group of 14 patients might formerly have been termed and treated as deceased but there were two patients ( 14.2 per cent), one in each treatment group, who survived intact and who justify our policy. ${ }^{42}$ 
There were 25 patients in the C.1 and C.2 categories, with a more hopeful prognosis, which have been combined in Table VII for a comparison of routine and H.Y.P.E.R. therapy. A significant statistical difference exists $(P<0.02)$ between the incidence of complete cerebral recovery in the partially treated group (35.7 per cent) and the fully treated (H.Y.P.E.R.) group (90.9 per cent). ${ }^{s s}$ Fortunately, the fear that a reduction in mortality by aggressive therapy might be associated with an increase in morbidity ${ }^{43}$ has not been confirmed ( 42.8 per cent reduced to 9.0 per cent).

In conclusion, the use of all H.Y.P.E.R. measures simultaneously for cerebral salvage appears justified in all near-drowning patients in category C. The success of these H.Y.P.E.R. measures has implications for the management of other conditions involving brain injury.

\section{ACKNOWLEDGEMENT}

The authors wish to thank the innumerable individuals at all levels of care who worked diligently in the best interests of these children. We thank Dr. M.M. Wood for the statistical analysis.

\section{REFERENCES}

1. Text: Dorland's Medical Dictionary, 24th Edition, W.B. Saunders Company, Philadelphia (March 1967.

2. Schuman, S.H., Rowe, J.R., Glazier, H.M. et al. "The Iceberg Phenomenon of NearDrowning." Soc. Crit. Care Med, , 4: 127, 1976.

3. Modell, J.H., Graves, S.A. \& Kuck, E.J. "Near-Drowning: Correlation of Level of Consciousness and Survival." Cdn. Anaes. Soc. J. 27: 211-215, 1980.

4. Conn, A.W., Edmonds, J.F. \& Barker, G.A. "Near-Drowning in Cold Fresh Water: Current Treatment Regimen." Canadian Anaesth. Soc. J., 25: 259-265, 1978.

5. Teasoale, Graham \& Jennett, Bryan. "Assessment of Coma and Impaired Consciousness." Lancet Vol. 2: 81-83 (13 July) 1974.

6. Lovejoy, F.H., SMITH, A.L., Bresnaw, M.J. el al. "Clinical Staging in Reye Syndrome." Am. J. Dis. Child. Vol. 128: 36-41, 1974.

7. Fandel, Ivar \& Bancalari, Eduardo. "Near-Drowning in Children: Clinical Aspects." Paediatrics 58: 573-579, 1976.

8. MODELL, J.H. "Drowning and Near-Drowning, Springfield, Illinois," Charles C. Thomas, 1971, pp. $4,5,6$.

9. Maclean, D. \& Emslie-SMith, D. "Accidental Hypothermia." Oxford, Blackwells Scientific Pubs., 1977, pp. 189, 383-384.

10. Fuller, R.N. "The Clinical Pathology of Human
Near-Drowning." Proc. Roy Soc. Med., 56: 35-38. 1963.

11. BARR, A.M. \& TAYLOR, N.L. "A Case of Drowning." Anaesthesia, 31: 651-657, 1976.

12. Conn. A.W., Edmonds. J.F. \& Barker, G.A "Cerebral Resuscitation in Near-Drowning." Paediatric Clinics of North America 26: 691-701, 1979.

13. Pearn, J., Nixon, J. \& Wilkey. I. "Freshwater Drowning and Near-drowning Accidents Involving Children: A 5-Year Total Population Study." Med. J. Austral., 2: 942-946, 1976.

14. Keatinge, W.R. "Survival in Cold Water." Oxford, Blackwells Scientific Pubs., 1969, pp 5 and 42.

15. Modell, J.H., Moya. F., Williams, N.D. \& WEIBLEY, T.C. "Changes in Blood Gases and A-a $\mathrm{DO}_{2}$ During Near-Drowning." Anaesthesiology 29: 456-465, 1968.

16. Petersen. B. "Morbidity of Childhood and Near-Drowning." Paediatries, 59: 364-370, 1977.

17. Trubuhovich, R. "Water International Accidents." N.Z.J. Sports Med. Supp \# 1: 48-54, May, 1976.

18. ConN, A.W. "The Role of Hypothermia in NearDrowning, Proceedings of 'Cold Water Symposium'." Royal Life Saving Society of Canada, May 8, 1976, pp. 33-35.

19. Marsh, M.L., Marshall, L.F. \& Shapiro, H.M. "Neurosurgical Intensive Care." Anesthesiology. 47: $149-163,1977$.

20. Shapiro, H.M. "Anaesthesia, Intensive Care and the Neurosurgical Patient." Am. Soc. Anaesth. Refresher Lecture Series, 1975.

21. Sмітн, A.L. "Barbiturate Protection in Cerebral Hypoxia." Anaesthesiology, 47: 285-293, 1977.

22. Hagerdal, M., Welsh, F.A., Keykhah, M. el al. "The Protective Effects of a Combination of Hypothermia and Barbiturates in Cerebral Hypoxia." Crit. Care Med. 6: 110-111, 1978.

23. Calderwood. H.W.. Modell, J.H. \& Ruiz, B.C. "The Ineffectiveness of Steroid Therapy for Treatment of Fresh-Water Near-Drowning." Anaesthesiology, 43:642-650, 1975 .

24. Fishman, R.A. "Brain Oedema." New Engl. J. Med., 293: 706-711, 1975.

25. Batzdorf, U. "The Management of Cerebral Oedema in Paediatric Practice." Paediatrics, 58: 78-87, 1976.

26. Black, P.R., VAN Devawter, S. \& Cohn, L.H. "Effects of Hypothermia on Systemic and Organic System Metabolism and Function." J. Surg. Res., 20: 49-63, 1976.

27. Modell, J.H. \& Davis, J.H. "The Electrolyte Changes in Human Drowning Victims." Anaesthesiology, 30: 414-420, 1969.

28. Fisk et al. "Influence of Duration of Circulatory Arrest at $20^{\circ} \mathrm{C}$ on Cerebral Changes." Anaesth. Intens. Care, 4: 126-134, 1976.

29. ViRTUE, R.W. "Hypothermic Anaesthesia." Springfield, Illinois, Charles C. Thomas, 1955.

30. CONN, A.W. "Near-Drowning and Hypothermia" (editorial). Canadian Med. Assoc. J., I20: 397-400. 1979.

31. Dominguez de Villota, E., Barat, G., Peral P. et al. "Recovery from Profound Hypothermia with Cardiac Arrest after Immersion." Brit. Med J., $4: 394,1973$. 
32. KVittingen, T.D. \& NaEss, A. "Recovery from Drowning in Fresh Water." Brit. Med. J., I: 1315-1317, 1963

33. King, R.B. \& Webster, I.W. "A Case of Recovery from Drowning and Prolonged Anoxia." Med. J. Austral., June 13, 1964, pp 919-920.

34. Siebre, H., Rod, T., Breivik, H. et al. "Survival after 40 minutes Submersion Withoul Cerebral Sequelae." Lancet 1: 1275-1277, 1975.

35. EDITORIAL: "Drowning and the Diving Reflex." Canad. Med. Assoc. J.. 108: 1209. 1973.

36. HuNT, P.K. "Effect and Treatment of Diving Refiex." Canad. Med. Assoc. J., /II: 1330-1331, 1974.

37. GoOden, B.A. "Drowning and the Diving Reflex in Man." Med. J. Austral., 2: 583-586, 1972.

38. Keatinge, W.R. "The Concept of Hypothermia, Proceedings of 'Cold Water Symposium?" Royal Life Saving Society of Canada, May 8, 1976.

39. ModelL, J.H. "Drowning and Near-Drowning." Springfield, Illinois. Charles C. Thomas, 1971, p. 70.

40. Gilston, Alan. "Cardiac Resuscitation Services: Principles and Practice." (Editorial) Int. Care Med. Vol. 5: 49-53, 1979.

41. Harries, Mark G. "Survival After Cardjac Arrest." International Med. I: 13-15, 1979.

42. Montes, J.E. \& Conn, A.W. "Near Drowning: An Unusual Case." Cdn. Anaes, Soc. Jour, 27: 172-174, 1980 .

43. Greene, David G. "Drowning." (Text) Handbook of Physiology Respiration II, Chapt. 50: $1245-1312,1965$

44. Giammona, S.T. "Drowning: Pathophysiology and Management." Curr. Probl. Paediat., $1: 1-33$, 1971.

45. Clarke, E.B. \& Niggemann, E.H. "Near Drowning." Heart and Lung. 4: 946-955, 1975.

46. Modell, J.H., Graves, S.A. \& Ketover, A. "Clinical Course of 91 Consecutive NearDrowning Victims." Chest Vol. 70: 231-238 (\#2 Aug.) 1976
47. HASAN S AVERY, W. G Fabian, C. \& SACKNER, M.A. "Near Drowning in Humans." Chest 59: 191-197, 1971.

48. Orlowski, J.P. "Prognostic Factors in Drowning and the Post-submersion Syndrome." Crit. Care Med., 6: 94, 1978.

49. Kruuss, Bergstrom L. \& Suutarinent HyvoNEN. R. "The Prognosis of Near-Drowned Children." ACTA Paediatr. Scand. 68: 315-322, 1979.

50. CAHIll, J.M. "Drowning: The Problem of Nonfatal Submersion and the Unconscious Patient." Surgical Clinics of North America 98: 423-430, 1968.

51. Battaglia, J.D. \& Lockhart, C.H. "Drowning and Near-Drowning." Paediatric Annals 98: 270-275 (April) 1977

52. HofF, B.H. "Multisystem Failure: A Review with Special Reference to Drowning." Crit. Care Med. 7: $310-320,1979$

53. Plum, F. \& Posner, J.B. " Diagnosis of Stupor and Coma." (Text) F.A. Davis Co., Philadelphia, 1st Edition, 1966

54. ShapiRo, H.M. "Intracranial Hypertension." Anaesthesiology, 43: 445-47I, 1975.

55. Wood, M.M. (H.S.C.) Personal Communication.

56. Alexander, S.C. \& Lassen, N.A. "Cerebral Circulatory Response to Acute Brain Disease." Anaesthesiology, 32: 60-68, 1970.

57. Spence, $M$. Personal Communication

58. Modell, J.H., Cilderwood, H.W. \& Ruiz, B.C. "Effects of Ventilatory Patterns on Arterial Oxygenation After Near-drowning in Sea Water." Anaesthesiology, 40: 376-384. 1974.

59. Text: "Drowning" Special Report. The Practitioner, April/May, 1979 Chapter - Sequelae of Near-Drowning. Simcock, A.D.

60. Froese, A.B. \& Bryan, A.C. Effects of anesthesia and paralysis on diaphragmatic mechanics in man. Anesthesiology 41: 242-255 (1974).

\section{RÉSUMÉ}

Ce travail décrit une classification neurologique simple pour les victimes de noyade. Trois catégories sont proposées

$$
\begin{aligned}
& \text { Catégorie A (conscience) } \\
& \text { Catégorie B (décébration) } \\
& \text { Catégorie C (coma). }
\end{aligned}
$$

La catégorie $C$ est subdivisée en trois classes:

Cl (décortication)

C2 (décébration)

C3 (flaccidité).

Cette classification est basée sur le niveau de conscience évalué une à deux heures après le sauvetage et sert de guide pour la mise en marche du traitment. Les résultats de récupération cérébrale chez 96 patients du Hospital for Sick Children de Toronto obtenus d'après cette classification sont rapportés en retrospective pour la période de 10 années allant de 1970 à 1979 inclusivement. Une thérapeutique neurologique agressive signifiait l'hydratation continue, l'hyperventilation contrôlée, l'hypothermie, le coma barbiturique et une curarisation continue pendant quatre jours.

Tous les patients des classes A $(51$ cas) et $\mathbf{B}$ (6 cas) ont récupéré complètement avec le traitement médical usuel.

Dans la catégorie C ( 39 comateux), la mortalité totale a été de 33.3 pour cent avec une morbidité cérébrale de 23.9 pour cent et une récupération à la normalité de $\mathbf{4 3 . 6}$ pour cent. Lors de la révision du résultat thérapeutique, deux sous-catégories $\mathrm{C} 1$ et $\mathrm{C2}$ ont été formées dans un but de comparaison. Chez 14 patients chez qui on avait employé le traitement usuel, 
on a trouvé une mortalité de 21.4 pour cent, une morbidité de 42.8 pour cent et une survie avec récupération totale de 35.7 pour cent. En comparaison, chez 11 patients traités de façon aggressive, il n'y a pas eu de mortalité, la morbidité a été de 9.0 pour cent et un taux significatif de 90.9 pour cent de survie sans séquelles a pu être constaté. Dans la sous-catégorie C3, (14 patients), il n'y a eu que quatre survivants dont un patient par groupe qui a récupéré complètement ( 14.2 pour cent).

Une survie avec une fonction cérébrale intacte est extrèmement importante. Nos données justifient une réanimation immédiate de toutes les victimes de noyade indépendemment de leur condition initiale ou du pronostic. L'emploi d'une classification neurologique précoce semble appropriée à la mise en marche du traitement qui doit être aggressif en cas de décortication (sous-catégorie $\mathrm{C}$ ) e et de décérébration (sous-catégorie $\mathrm{C2}$ ), dans le but de produire une réduction importante de la morbidité et de la mortalité chez les victimes de noyade. 